\title{
Variation in plasma glucose and pancreatic $\beta$ cells in the turtle, Lissemys punctata (order: Chelonia; family: Trionychidae)
}

\author{
Vidya R. Chandavar ${ }^{1}$ and Prakash R. Naik
}

Department of Studies in Zoology, University of Mysore, Manasagangorti, Mysore, 570006, India

${ }^{1}$ Present address: Yuvaraja's College, University of Mysore, Mysore, 570005, India

\section{Keywords:}

$\beta$ cell; Lissemys punctata; plasma glucose; seasonal variation; turtle

Accepted for publication: 17 May 2004

\begin{abstract}
Chandavar, V. R. and Naik, P. R. Variation in plasma glucose and pancreatic $\beta$ cells in the turtle, Lissemys punctata (order: Chelonia; family: Trionychidae). Acta Zoologica (Stockholm) 85: 113-118

The present study relates to the determination of the plasma glucose level and volumetric analysis of $\beta$ cells in pancreatic islets of the soft-shelled turtle Lissemys punctata during different phases of its reproductive cycle. Reproductive events play a vital role in influencing the plasma glucose level and $\beta$-cell behaviour in the pancreatic islets. The colour of the pancreas is either yellowish or pinkish, depending on endocrine activity. Islets are present throughout the gland and range from individual cells to small or large clumps, depending on the seasonal cycle. Splenic islets are dense with more blood capillaries and nerve innervations irrespective of sex and season. The endocrine cell mass forms irregular patches without connective tissue capsule. $\beta$ cells occupy the inner region of the islets, being surrounded by other cell types. Lissemys punctata exhibits higher $\beta$-cell activity during hibernation. Most insulin-secreting cells acquire a larger size during the regressive period. An analysis indicates that $\beta$ cells outnumber the non- $\beta$ endocrine cell mass in both number and per cent volume. There is negative correlation between islet mass and animal weight. Between the periods of reproductive cycles, a difference exists with respect to fasting plasma glucose and $\beta$-cell volume.
\end{abstract}

Prakash. R. Naik, Department of Studies in Zoology, University of Mysore, Manasagangorti, Mysore. 570006. India. E-mail: prakashrnaik@yahoo.co.in

\section{Introduction}

Plasma makes up $60-80 \%$ of blood volume and consists of a variety of substances in reptiles as in other vertebrates. Dessauer (1970) reports that the concentration of glucose in blood varies with the season in many reptiles, such as testudians, squamata and crocodilia. Daily events as well as seasonal metabolic cycles are observed to influence blood glucose in reptiles. Remarkably little knowledge is available with reference to fasting plasma glucose levels and activities of the pancreatic islet cells in untreated reptiles. Miller and Wurster (1956) have studied the relationship between plasma glucose and the pancreatic islets of normal and treated lizards. However, no study has been carried out on turtles in this regard. Correa et al. (1960) investigated the fate of $\beta$ cells during oral administration of glucose in the turtle Chrysemys dorbigini. Later, Muniz and Marques (1989) in the same species found qualitative changes in the endocrine pancreas from hyperglycaemic streptozotocin treatment. Recently, Ray and Maiti (2001) reported a positive correlation between ambient temperature and blood glucose in Lissemys punctata. The blood plasma of turtles contains glucose in moderate concentrations while in lizards the glucose level is consistently higher than in other reptiles (Dessauer 1970; Chandavar 2002). Physiological events are accompanied by substantial fluctuations in plasma glucose. Glucose regulation is dependent on the $\beta$-cell volume in all major groups of vertebrates. The objective of the present investigation is to understand the correlation between these parameters in L. punctata.

\section{Materials and Methods}

The winter-hibernating Indian turtle L. punctata exhibits adaptation to a variety of environments. They remain concealed in loose soil or in water during hibernation. After hibernation, they become voracious eaters and hyperactive. 
Table 1 Ambient temperature, seasonal cycle and reproductive events in Lissemys punctata

\begin{tabular}{llll}
\hline & Reproductive periods & & \\
\cline { 2 - 4 } Parameter & Regenerative & Reproductive & Regressive \\
\hline Months & March-June & July-August & September-February \\
Seasons & Summer & Monsoon & Winter \\
Temperature range & $37-19^{\circ} \mathrm{C}$ & $28-19^{\circ} \mathrm{C}$ & $28-11^{\circ} \mathrm{C}$ \\
Reproductive stage & Initiation of gonadal activity & Well developed sperms and ova Mating occurred & Regression of gonads \\
Activity of animals & Hyperactive & Active and aggressive & Sluggish, hibernating \\
\hline
\end{tabular}

Their sex ratio is maintained at $1: 1$ (Das 1995). Singh (1974, 1977) reported the reproductive cycle of L. punctata. On average, the animals weigh between 900 and $2400 \mathrm{~g}$.

Adult animals of both sexes were collected from their natural habitat, Kabini reservoir (latitude $11^{\circ} 0^{\prime} 30^{\prime \prime} \mathrm{N}$; longitude $76^{\circ} 21^{\prime} 12^{\prime \prime} \mathrm{E}$; catchment area $2142 \mathrm{~km}^{2}$, about $60 \mathrm{~km}$ away from Mysore) and were maintained in an outdoor cement tank containing water and sand. The cistern measured $7 \times 5 \times 5$ feet $(2.1 \times 1.5 \times 1.5 \mathrm{~m})$ with a raised bottom at one end for basking. The animals were fed fresh carrot and spinach ad libitum, but were not fed $48 \mathrm{~h}$ prior to autopsy. During experimentation the ambient temperature of Mysore varied with the season $\left(11-37^{\circ} \mathrm{C}\right)$. The reproductive events in L. punctata differed with respect to season (Table 1).

Four animals of L. punctata were used in each season. They were anaesthetized with chloroform and their body measurements and weights were recorded. They were killed by decapitation and blood samples were collected from the carotid artery. The blood samples were centrifuged at $4{ }^{\circ} \mathrm{C}$ at $6622 \mathrm{~g}$ for $10 \mathrm{~min}$. The separated serum was used for estimation of plasma glucose by the enzyme glucose oxidase method. The estimation was done using Dr Reddy's GOD/POD Kit (Plummer 1987) and Spectrophotometer, BIO-TEK Instruments, INC (USA) Model $\mu$ Quant. The glucose kit is based on Trinders's method in which glucose oxidase (GOD) and peroxidase (POD) enzymes are used along with the chromogen 4 -aminoantipyrine and phenol. The enzyme GOD gives D-gluconic acid and hydrogen peroxide oxidizes glucose. Hydrogen peroxide in the presence of the enzyme POD oxidizes phenol, which combines with 4-aminoantipyrine to produce a red-coloured quinone-imine dye. Plasma glucose was determined for all the seasons by averaging the values of multiple samples from active animals maintained at room temperature under fasting conditions for $48 \mathrm{~h}$.

Meanwhile, the pancreas was removed, fixed in BouinHollande solution, processed and sectioned $(4-\mu \mathrm{m})$ for light microscopy. Every fifth oxidized slide was stained with chrome alum haematoxylin phloxin (CHP) and phosphotungstic acid was used as a mordant after acidification, slightly modified after Gomori (1941). $\beta$-cell count was performed at regular intervals throughout the pancreas. Only those islet cells in which the nucleus was visible were counted using the blood cell counter. The density of $\beta$ cells was calculated with respect to non- $\beta$-cell mass during each period. The size of islets, and $\beta$ cells was calculated by random selection of at least 100 observations for each season.

Statistical analysis of $\beta$-cell count, $\beta$-cell density and per cent plasma glucose level for different periods was carried out using analysis of variance (ANOvA). Wherever the variance value was found to be significant at 5\%, Duncan's Multiple Range Test (DMRT) was applied. Statistical presentation was organized using STATISTICAL PRESENTATION SYSTEM SOFTWARE (SPSS), Windows version 10.0, 1999, New York. SPSS Inc.

\section{Results}

The females of L. punctata start laying eggs in clutches by the end of August and continued until October. The regressive period corresponded with winter (September-February); both the sexes exhibited low physical activity and underwent hibernation, which continued until the onset of summer (March) (Table 1).

\section{Observations on plasma glucose levels}

During the regressive period, fasting plasma glucose level was the lowest $(91.39 \pm 2.76 \mathrm{mg} \%)$. It increased to $96.87 \pm$ $3.63 \mathrm{mg} \%$ during the regenerative period and reached a peak value of $119.27+1.68 \mathrm{mg} \%$ during the reproductive period (Fig. 1). There was no significant variation in the plasma glucose level between the sexes. However, such a variation existed when the data for mean glucose level were compared between regenerative and reproductive, and reproductive and regressive periods. An $F$-value of 34.22 with 2 and 85 degrees of freedom was found to be highly significant $(P<0.01)$. Between the regressive and regenerative periods the differences were not significant.

\section{Light microscopic observations}

The pancreas showed a number of islets of varying sizes in all its regions. Larger islets were seen in the splenic region with dense endocrine cells and more blood capillaries containing red blood cells besides nerve innervations irrespective of the sex and season. The islets were irregular in shape and devoid of connective tissue capsules. They orientated towards the 


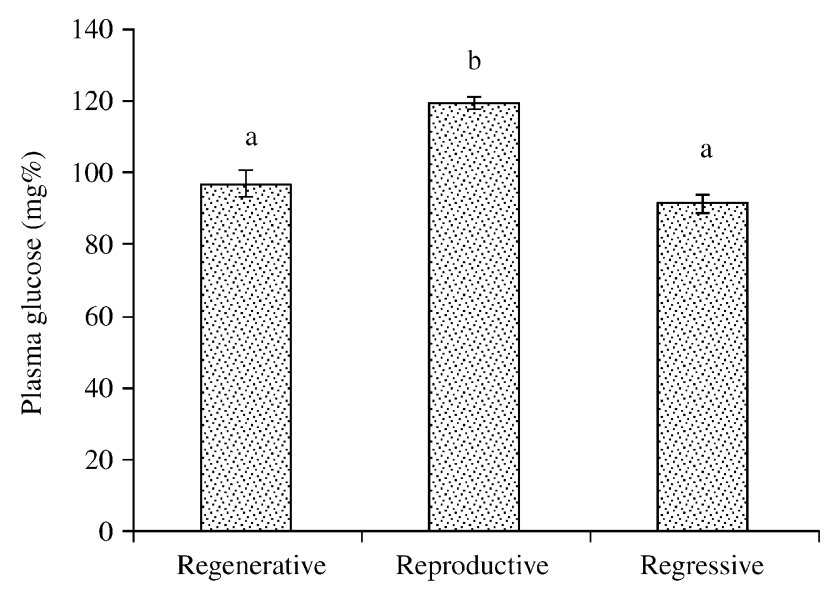

Fig. 1-Seasonal variation in plasma glucose in Lissemys punctata. Data are the means \pm SD of 40 observations in each period. $P<0.01$ between regenerative and reproductive; reproductive and regressive periods.

blood vessel or towards the ducts. Endocrine cells stained darker than the surrounding exocrine tissue under $\mathrm{CHP}$ staining. The length and weight of the pancreas also varied with season, being highest in the regressive period (Table 2). On average, the pancreas was $8.97 \pm 1.9 \mathrm{~cm}$ in length and $1.539 \pm 0.45 \mathrm{~g}$ in weight.

During the regenerative period, the endocrine cells were present throughout the pancreas as individual cells or as smaller aggregations between the acini. The islets had a mean size of $1.715 \pm 1.1 \mathrm{~mm}$. The total $\beta$-cell volume was $71.67 \pm$ $10.28 \%$ of the islets. The pancreas of the reproductive animals also had endocrine cells throughout but in smaller clumps between the exocrine tissues. The mean size of the islet measured $0.83 \pm 0.3 \mathrm{~mm}$. The volume of $\beta$ cells was $67.99 \pm 17.8 \%$ in comparison to the proportion during the regenerative period. During the regressive period, the pancreas of L. punctata showed a higher number of larger islets throughout, with tightly packed endocrine cells. The average size of the islet was $2.659 \pm 1.8 \mathrm{~mm}$ and the volume of $\beta$ cells was $84.91 \pm 8.8 \%$ of the islet. During this period, the islets were also found concentrated towards pancreatic periphery. No individual endocrine cells were seen between the exocrine tissues. Macrophages were a common occurrence in the pancreas of these animals.

$\beta$ cells were ovoid, blue-stained, with central oval or lobed nuclei, rich in haematoxylin-positive granules. The cells were, on average, $4.7 \pm 0.95 \mu \mathrm{m}$ at their longest axis. The islet cells were smaller or equal to the size of nuclei of exocrine cells. The $\beta$-cell size remained the same irrespective of the pancreatic region, sex and age of the animals, but some of the largest, measuring up to $7 \mu \mathrm{m}$, were found in regressive periods. The size of the islets varied from $0.2 \mathrm{~mm}$ to $9.8 \mathrm{~mm}$ with a mean value of $2.52 \pm 1.8 \mathrm{~mm}$ at their longest axis. Morphometric analysis showed that the $\beta$ cells were the most abundant, amounting to approximately $73 \%$ of the endocrine pancreatic mass.

Analysis of data indicated that there was a significant difference in mean $\beta$-cell volume and cell count between the periods of the annual reproductive cycle. The averaged values represent orders of magnitude rather than fixed levels, as the range of variability was great between individuals of this population.

\section{Discussion}

The weight of the animal and its pancreas varied with season (Table 2). The structure of the pancreas of L. punctata remained the same as described by Miller and Lagios (1970). The colour of the pancreas varied from pinkish to yellowish depending on the phases of the reproductive cycle. The plasma glucose level in L. punctata starved for 2 months was 46 mg\% (Dessauer 1970) whereas Padgaonkar and Mehendale (1986) reported $79.98 \mathrm{mg} \%$ after 48 -h starvation in $L$. punctata granosa. In the present investigation, higher values are exhibited (91.39-119.27 $\mathrm{mg} \%$ ) for this parameter during different periods of reproduction, although the period of starvation was comparable with that used by Padgaonkar and Mehendale (1986). The difference in the plasma glucose

Table 2 Morphometric measurements of animal and pancreas in different periods of the reproductive cycle

\begin{tabular}{|c|c|c|c|c|c|}
\hline \multirow[b]{2}{*}{ Parameter } & \multicolumn{3}{|c|}{ Reproductive periods } & \multicolumn{2}{|c|}{ Statistical analysis } \\
\hline & Regenerative & Reproductive & Regressive & $F$-value & $P$-value \\
\hline $\begin{array}{l}\text { Animal weight }(\mathrm{g}) \\
\text { (mean } \pm \mathrm{SD} \text { ) }\end{array}$ & $1460 \pm 432.56$ & $1560 \pm 424.78$ & $1390 \pm 284.60$ & 0.488 & 0.619 \\
\hline $\begin{array}{l}\text { Carapace length }(\mathrm{cm}) \\
(\text { mean } \pm \mathrm{SD})\end{array}$ & $22.6^{a} \pm 2.1$ & $24.7^{b} \pm 1.9$ & $21.9^{a} \pm 1.7$ & 5.218 & 0.012 \\
\hline $\begin{array}{l}\text { Pancreas weight }(\mathrm{g}) \\
(\text { mean } \pm \mathrm{SD})\end{array}$ & $1.509 \pm 0.64$ & $1.532 \pm 0.34$ & $1.577 \pm 0.32$ & 0.067 & 0.936 \\
\hline $\begin{array}{l}\text { Pancreas length }(\mathrm{cm}) \\
\text { (mean } \pm \mathrm{SD})\end{array}$ & $8.57 \pm 1.74$ & $8.44 \pm 1.8$ & $9.91 \pm 1.9$ & 1.729 & 0.196 \\
\hline
\end{tabular}

Means with same letters are not significantly different from each other. 
level recorded by these investigators and that observed by the present investigators could be attributed chiefly to differences in the diet fed to the experimental animals, to different periods of reproduction and to their ecotypes. Obviously, a highly reduced plasma glucose level recorded by Dessauer (1970) is an impact of prolonged starvation possibly coupled with differences in the diet as well as the ecotype of L. punctata. Under the CHP method, the islets were darkly stained as compared to mammalian islets. They were irregular, without connective tissue capsules. Comparable findings were also recorded in the turtles Testudo graeca L. and Mauremys caspica (Garcia Ayala et al. 1987, 1989). Endocrine cells in L. punctata were smaller or similar to the size of acinar cell nucleus. In the islets, $\beta$ cells usually occupy the central region surrounded by other cell types. Most of the islets were orientated towards the blood capillaries, indicating their endocrine property. The islet cells in L. punctata were present throughout the pancreas either as individual cells, as small groups, or as large clusters, splenic islets being the largest. Gapp et al. (1985) found pancreatic endocrine cells in the turtle Chrysemys picta scattered as single cells or as small aggregates throughout the exocrine tissue. In turtles, crocodilians and certain squamata, the islets were scattered throughout the gland (Epple and Brinn 1987). Some differences in the distribution and morphological features of pancreatic endocrine cells have been observed in $M$. caspica during summer and winter despite not showing any decrease in vital activities (Garcia Ayala et al. 1989).

During the regenerative period of L. punctata, many $\beta$ cells were seen individually and a few were in small clusters. Individual cells were less common in the reproductive period; they were not prominent in the regressive period. Interestingly, whenever the total $\beta$-cell count declined, the animals exhibited higher plasma glucose levels irrespective of the season. The females showed comparatively higher plasma glucose values and denser islet cell masses than the males in all seasons. The islets reported in the turtles Pseudemys scripta (Agulleiro et al. 1985), Testudo graeca L. (Garcia Ayala et al. 1987), and Mauremys caspica (Garcia Ayala et al. 1989) were mostly small but showed trends of developing into larger islets. Hoet et al. (1995) have reported that new $\beta$ cells could be produced at the rate of $4-10 \%$ at different glucose concentrations in glucose-treated animals.

In L. punctata, the islets were also orientated towards the duct, particularly in the regressive period. Some of the larger duct walls exhibited the presence of $\beta$ cells in them as a bluestained cell mass. In cyclostomes, as reported by Epple and Brinn (1987), the islets develop directly from the bile duct cells which, according to Bonner-Weir (2000) could be facultative cells.

The average weight of the animals during the regressive period was low but the average weight of the pancreas remained comparatively high (Table 2). The size of the islets was also largest, with the highest number of endocrine cells. There was a negative correlation between islet mass and

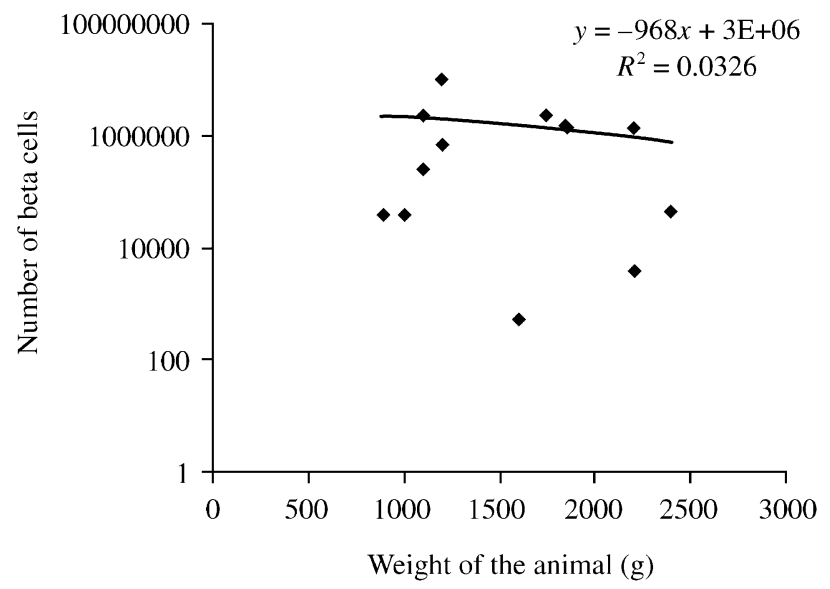

Fig. 2 - Relationship between body weight and islet mass calculated by taking $\beta$-cell count as an indirect measure of islet mass in Lissemys punctata. Actual data of all animals used in the experiment irrespective of sex and season are given.

animal weight (Fig. 2) though it varied at the individual level. In general, the larger the animal, the smaller the islet size and cell count. $\beta$ cells were found throughout the pancreas, being more numerous in the splenic region in L. punctata. These observations are in conformity with those reported in $M$. caspica in which insulin-secreting cells were more abundant in the splenic pancreas than in the duodenal region during winter, but were found distributed uniformly throughout the gland in summer (Garcia Ayala et al. 1989). By contrast, the distribution of these cells did not differ between summer and winter in T. graeca (Garcia Ayala et al. 1987). Lissemys punctata during the regressive period showed the lowest plasma glucose, higher glycogen localization in the liver and excessive white and brown fat deposition in the abdominal cavity; the pancreas appeared predominantly pinkish because of its higher blood supply and highest $\beta$-cell count. Fat accumulated during the regressive period underwent a steady decline from the regenerative to the reproductive period, indicating its utilization in the reproductive activity of the animals. The basal metabolic rate in poikilotherms during hibernation is maintained by higher levels of thyroxin from the thyroid gland (Lynn 1970). Thyroxin promotes the breakdown of glucose and brown fat to provide energy, which is important for hibernating animals because it helps to raise the core temperature rapidly during waking from hibernation (Taylor et al. 1997). The thyroid gland of regressive animals of $L$. punctata also exhibited higher colloidal content in the follicles.

In the present investigation, some of the $\beta$ cells of $L$. punctata during the regressive period pooled their granules into the blood capillaries and were seen as accumulations of secretory granules on the exterior of the cell membrane. Most of the $\beta$ cells grew larger during this period; some of these were stained pale blue, presumably because they had emptied their secretory content. Hypertrophy of the cells was to meet 
increased demand for insulin to enhance glucose uptake by peripheral tissues. There was a marked increase in the number of macrophages in the vicinity of the islets, probably to weed out the older $\beta$ cells. Hypertrophy of the cell is reported to be a sustained amplification of gene expression without cell division (Bonner-Weir 2000).

The $\beta$ cells were less abundant during the regenerative period and became least abundant during the reproductive period. Plasma glucose level was higher during the reproductive period as opposed to the regenerative and regressive periods. A rise in temperature is reported to increase glucose level in alligators and in the snake Vipera aspis (Dessauer 1970) as well as in L. punctata (Ray and Maiti 2001), but to cause a fall in glucose in the turtle Emys orbicularis (Dessauer 1970); glucose rises sharply in Pseudemys subjected to a sudden drop in temperature (Dessauer 1970). During the transition from the reproductive to regressive period, blood glucose might have influenced the proliferation of $\beta$ cells in L. punctata. Higher blood glucose levels in this turtle may be attributed to larger numbers of insulin-producing $\beta$ cells, which were in a hypertrophied condition. Insulin secretion from these cells may have a significant role to play in the carbohydrate metabolism in L. punctata. The $\beta$-cell population has a slow turnover, with cell renewal coming from replication of pre-existing $\beta$ cells and from differentiation of cells that act as precursors in the adult ductal epithelium (Bonner-Weir 2000). In the present study, it was observed that $\beta$-cell mass remained dynamic. Though $\beta$-cell mass along with non- $\beta$ cells increased significantly from the reproductive to the regressive period, there was no evidence for mitotic cell division. There is experimental evidence that $\beta$-cell mass can increase or decrease (Bonner-Weir 2000) and they must have a finite life span like other cell types. Meanwhile, regenerative and early reproductive animals had little or no fat deposition in and around the viscera. The pancreas appeared yellowish, making it difficult to separate the organ from duodenum whenever the animals had increased fat deposition in and around the viscera. The animals became voracious eaters after the termination of hibernation and only excess carbohydrate was deposited as fat. With the increase in ambient temperature from March onwards they became more active and initiated gonadal activity, which reached its peak in the reproductive period. Owing to the lesser density of $\beta$ cells, the plasma glucose increased progressively from the regenerative to the reproductive period. Variation in the colour of the pancreas depended on blood supply, which in turn appeared to be dependent on endocrine activity, which was higher during the regressive period when $L$. punctata had significantly higher plasma glucose (average $102.51 \pm 5.37 \mathrm{mg} \%$ ). Unsurprisingly, Dessauer (1970) has reported a highly reduced (33$91 \mathrm{mg} \%$ ) plasma glucose level when the testudians were subjected to starvation for a period of 2 months. The plasma glucose estimated for the reptile Chrysemys dorbigini during summer and winter ranged from 76 to $95 \mathrm{mg} \%$. He also observed that plasma insulin reached its peak in winter when blood glucose was at a minimum. Similarly, a comparable plasma glucose level (69.97-119.27 mg\%) was observed in this reptile ( $C$. dorbigini) during different periods of reproduction (Correa et al. 1960).

The organization of blood sugar levels in reptiles is poorly understood. Along with other metabolic demands, glucose is also a stimulant factor for $\beta$-cell regeneration and vice versa. Change in plasma glucose is dependent on $\beta$-cell number and physiological events of the reproductive cycle. This in turn depends on the ambient temperature and/or seasonal cycle of the animal in a particular location.

\section{Acknowledgements}

The first author gratefully acknowledges the University of Mysore for the award of a teacher fellowship.

\section{References}

Agulleiro, B., Garcia Ayala, A. and Abad, M. E. 1985. An immunocytochemical and ultrastructural study of the endocrine pancreas of Pseudemys scripta elegans (Chelonia). - General and Comparative Endocrinology 60: 95-103.

Bonner-Weir, S. 2000. Islet growth and development in the adult. fournal of Molecular Endocrinology 24: 297-302.

Chandavar, V. R. 2002. Comparative histophysiology of endocrine pancreas in selected species of reptiles. PhD Thesis. University of Mysore, India.

Correa, P. R., Marques, M. and Wagner, E. M. 1960. Hyperglycemia caused by the oral administration of glucose in turtles. Endocrinology 66: 731-734.

Das, I. 1995. Turtles and Tortoises of India. - World Wide Fund for Nature India. Oxford University Press, Bombay, Delhi.

Dessauer, H. C. 1970. Blood chemistry of reptiles: physiological and evolutionary aspects. In Gans, C. and Parsons, T. S. (Eds): Biology of the Reptilia, Vol. 3, pp. 1-54. Academic Press, London and New York.

Epple, A. and Brinn, J. E. 1987. The Comparative Physiology of the Pancreatic Islets, 223pp. Springer Verlag, Berlin.

Gapp, D. A., Kenney, M. P. and Polak, J. M. 1985. The gastroentero-pancreatic system of the turtle Crysemys picta. - Peptides 6: 347-352.

Garcia Ayala, A., Lozano, M. T. and Agulleiro, B. 1987. Endocrine pancreas of Testudo graeca L. (Chelonia) in summer and winter: an immunocytochemical and ultrastructural study. - General and Comparative Endocrinology 68: 235-248.

Garcia Ayala, A., Lozano, M. T. and Agulleiro, B. 1989. Comparative study on the endocrine cells in the pancreas of Mauremys caspica (Chelonia) in summer and winter. - General and Comparative Endocrinology 75: 363-375.

Gomori, G. 1941. Observations with differential stains on human islets of Langerhans. - American fournal of Pathology 17: 395-406.

Hoet, J. J., Reusens, B. and Remacle, C. 1995. Anatomy, Developmental Biology and Pathology of Pancreatic Islets. In DeGroot, L. J., Besser, M., Burger, H. G. et al. (Eds). Endocrinology, Vol. 2, p. 1282. Saunders Company W.B., Philadelphia London Toronto Montear Sydney Tokyo.

Lynn, W. G. 1970. The thyroid. In Gans, C. and Parsons, T. S. (Eds): Biology of the Reptilia, Vol. 3, pp. 201-234. Academic Press, London and New York. 
Miller, M. R. and Wurster, D. H. 1956. Studies on the blood glucose and pancreatic islets of lizards. - Endocrinology 58: 114-120.

Miller, M. R. and Lagios, M. 1970. The pancreas. In Gans, C. and Parsons, T. S. (Eds): Biology of the Reptilia, Vol. 3, pp. 319-346. Academic Press, London and New York.

Muniz, W. W. and Marques, M. 1989. Glycemia and immunohistochemical changes in the endocrine pancreas of the turtle Chrysemys dorbigini treated with streptozotocin. - Brazilian fournal of Medical and Biology Research 22: 1033-1037.

Padgaonkar, A. S. and Mehendale, M. S. 1986. Hyperglycemia and beta cell damage caused by glucose administration in the turtle, Lissemys punctata granosa (Boulenger). - fournal of Current Bioscience 3: 55-56.

Plummer, D. T. 1987. An Introduction to Practical Chemistry, pp. 181-182. Tata McGraw-Hill Co Limited, New Delhi.
Ray, P. P. and Maiti, B. R. 2001. Adrenomedullary hormonal and glycemic responses to high ambient temperature in the soft-shelled turtle, Lissemys punctata punctata. - General and Comparative Endocrinology 122: 17-22.

Singh, D. P. 1974. Analysis of environmental factors regulating the gonadal cycle in a tropical pond turtle, Lissemys punctata granosa (Schoeff). - Experientia 30: 967-968.

Singh, D. P. 1977. Animal sexual rhythm in relation to environmental factors in a tropical pond turtle, Lissemys punctata granosa.Herpetologica 33: 190-194.

Taylor, D. J., Green, N. P. O. and Stout, G. W. 1997. Thyroid gland and temperature regulation. In Soper, R. (Ed.): Biology Science, Vol. 3, pp. 605-659. Cambridge University Press, Cambridge. 